\title{
Effect of smoking on comparative efficacy of antiplatelet agents: systematic review, meta-analysis, and indirect comparison
}

\author{
Joshua J Gagne assistant professor, Katsiaryna Bykov pharmacoepidemiologist, Niteesh K Choudhry \\ associate professor, Timothy J Toomey research assistant, John G Connolly research assistant, \\ Jerry Avorn professor and division chief
}

Division of Pharmacoepidemiology and Pharmacoeconomics, Department of Medicine, Brigham and Women's Hospital and Harvard Medical School, 1620 Tremont Street, Suite 3030, Boston, MA 02120, USA

\begin{abstract}
Objective To evaluate whether smoking status is associated with the efficacy of antiplatelet treatment in the prevention of cardiovascular events.

Design Systematic review, meta-analysis, and indirect comparisons.

Data sources Medline (1966 to present) and Embase (1974 to present), with supplementary searches in databases of abstracts from major cardiology conferences, the Cumulative Index to Nursing and Allied Health (CINAHL) and the CAB Abstracts databases, and Google Scholar.

Study selection Randomized trials of clopidogrel, prasugrel, or ticagrelor that examined clinical outcomes among subgroups of smokers and nonsmokers.
\end{abstract}

Data extraction Two authors independently extracted all data, including information on the patient populations included in the trials, treatment types and doses, definitions of clinical outcomes and duration of follow-up, definitions of smoking subgroups and number of patients in each group, and effect estimates and 95\% confidence intervals for each smoking status subgroup.

Results Of nine eligible randomized trials, one investigated clopidogrel compared with aspirin, four investigated clopidogrel plus aspirin compared with aspirin alone, and one investigated double dose compared with standard dose clopidogrel; these trials include 74489 patients, of whom 21717 (29\%) were smokers. Among smokers, patients randomized to clopidogrel experienced a $25 \%$ reduction in the primary composite clinical outcome of cardiovascular death, myocardial infarction, and stroke compared with patients in the control groups (relative risk $0.75,95 \%$ confidence interval 0.67 to 0.83 ). In nonsmokers, however, clopidogrel produced just an $8 \%$ reduction in the composite outcome $(0.92,0.87$ to 0.98$)$. Two studies investigated prasugrel plus aspirin compared with clopidogrel plus aspirin, and one study investigated ticagrelor plus aspirin compared with clopidogrel plus aspirin. In smokers, the relative risk was 0.71 ( 0.61 to 0.82$)$ for prasugrel compared with clopidogrel and 0.83 (0.68 to 1.00) for ticagrelor compared with clopidogrel. Corresponding relative risks were 0.92 (0.83 to 1.01) and 0.89 (0.79 to 1.00$)$ among nonsmokers.

Conclusions In randomized clinical trials of antiplatelet drugs, the reported clinical benefit of clopidogrel in reducing cardiovascular death, myocardial infarction, and stroke was seen primarily in smokers, with little benefit in nonsmokers.

\section{Introduction}

Antiplatelet drugs have become vital in the treatment of acute coronary syndromes. Randomized clinical trials have consistently found that clopidogrel, which has been available for nearly two decades and is the most commonly used adenosine diphosphate receptor blocker, reduces the incidence of fatal and nonfatal cardiovascular events in patients with acute coronary syndrome. Compared with treatment with aspirin alone, dual treatment with aspirin plus clopidogrel has been found to reduce the rate of death and myocardial infarction and stroke by $15 \%$ in patients with acute coronary syndrome. ${ }^{1}$ Subgroup analyses of randomized controlled trials, however, have recently raised the question of whether such efficacy occurs primarily or exclusively among smokers. ${ }^{2}$

Clopidogrel is a prodrug that requires a two step metabolic activation process to attain its active form. Cigarette smoking induces the cytochrome P450 isoenzyme 1A2, a key enzyme involved in the first activation step. Some authors have hypothesized that smoking therefore increases the availability of clopidogrel's active metabolite, enhancing its efficacy. Among the newer antiplatelet agents, prasugrel is also a prodrug but it undergoes a less complex activation process that is not believed to involve CYP1A2; ticagrelor is itself an active moiety 
whose metabolism only slightly involves CPY1A2. Therefore, we hypothesized that the efficacy of clopidogrel, but not that of prasugrel and ticagrelor, would be enhanced among smokers. We carried out a systematic review, meta-analysis, and series of indirect comparisons to quantify the efficacy of clopidogrel separately in smokers and nonsmokers and to compare the efficacy of newer antiplatelet agents in these groups of patients.

\section{Methods}

We followed the PRISMA guidelines for the conduct and reporting of systematic reviews. ${ }^{3}$

\section{Search strategy and study selection}

We systematically searched Medline and Embase databases up to 18 July 2013 with no date or language restrictions. We searched for all human randomized controlled trials evaluating clopidogrel, prasugrel, or ticagrelor. Detailed search strategies for each database are listed in the appendix. After excluding duplicates, two authors (TJT and JGC) independently screened the titles and abstracts of all identified articles to exclude those that were not randomized trials, did not examine clinical outcomes (such as only assessed platelet reactivity), or were otherwise not relevant to our objectives. We obtained full text versions of all remaining articles. We electronically searched these articles for the word stems "smok*" and "tobacco" to determine whether they were mentioned in the articles in any places other than in the tables describing characteristics of patients. We also searched for mention of the availability of supplementary data using such terms as "appendi*", "online", and "supplement". We further reviewed the supplementary materials for any mention of smoking or tobacco use. Two authors (JJG and KB) evaluated each article that mentioned smoking beyond the first table in either the main paper or supplementary appendix and included in the final analysis those studies that reported clinical outcomes of antiplatelet treatment in one or more smoking subgroups. Discrepancies at any stage in the review process were resolved by group consensus.

In addition to the systematic search process, we searched for studies in major cardiology conference abstract databases (American Heart Association, American College of Cardiology, European Society of Cardiology, and Heart Rhythm Society), in the Cumulative Index to Nursing and Allied Health (CINAHL) and the CAB Abstracts databases, and using Google Scholar. We also retrieved other meta-analyses of antiplatelet agents and reviewed the studies included in those to identify additional studies that might have been missed by the other search strategies. Finally, we manually searched the reference lists of relevant articles to locate additional studies.

\section{Data extraction}

From each study included in the analysis, we extracted information about the antiplatelet treatment group, the control treatment group, the definition of each clinical outcome, the definition of smoking subgroups, the number of patients in each smoking category, and hazard ratio and $95 \%$ confidence interval for each subgroup specific effect, or the information required to calculate these. We used the Cochrane risk of bias tool to assess whether studies were at low, high, or unclear risk of selection bias, performance bias, detection bias, attrition bias, or reporting bias. ${ }^{4}$ Protocols and design and rationale papers associated with each study were consulted as needed when available. Two authors (JJG and KB) independently performed all data extraction in duplicate and discrepancies were discussed until agreement was met.

\section{Data analysis}

Our primary analysis was a fixed effects meta-analysis of hazard ratios examining clopidogrel with or without aspirin compared with aspirin alone or lower dose clopidogrel plus aspirin (collectively referred to as "control arms") separately among smokers and nonsmokers. We focused on a composite clinical outcome comprising cardiovascular death, myocardial infarction, and stroke, which was the primary outcome for all but one study included in the analysis, in which it was a secondary endpoint. ${ }^{5}$ When studies reported results at multiple time points (for example, at 28 days and at one year), we used the longer follow-up time. When permitted by the data from the original studies, we classified current smokers as smokers and never and former smokers as nonsmokers. When studies reported results for more than two smoking categories (for example, separate estimates for former smokers, nonsmokers, and current smokers), we used fixed effects meta-analyses to combine groups as necessary (such as combining former and nonsmokers). Presence of heterogeneity was assessed with the Cochrane $Q$ test and quantified with the $\mathrm{I}^{2}$ test.

We conducted sensitivity analyses by omitting each study, one at a time, from the primary analysis. For the CLARITY-TIMI 28 study, we also conducted a sensitivity analysis in which we used that trial's primary composite endpoint of thrombolysis in myocardial infarction (TIMI) flow grade (TFG) 0 or 1 or death or recurrent myocardial infarction before angiography could be performed. ${ }^{6}$ Finally, we assessed the potential for publication bias by visually inspecting the funnel plot. ${ }^{7}$

Two studies examined prasugrel plus aspirin compared with clopidogrel plus aspirin; we combined them using a fixed effects meta-analysis separately for smokers and nonsmokers. We then used indirect analyses to compare prasugrel and ticagrelor with the control arms from the original clopidogrel trials and to compare prasugrel with ticagrelor. We used Bucher's method to make each of the three pairwise indirect comparisons separately. ${ }^{8}$

\section{Results}

\section{Literature search}

We identified 1190 unique articles from the Medline and Embase searches, of which we excluded 1021 based on the title and abstract screening. From the remaining 169 articles, we further excluded 153 that did not mention smoking or tobacco except as a baseline characteristic and nine articles that mentioned smoking but did not present smoking related subgroup findings. The other search strategies yielded two additional studies, resulting in a total of nine studies that we included in analyses (fig 1) $\downarrow$. $^{6-23}$

Six studies evaluated clopidogrel as the intervention of interest: one examined clopidogrel alone compared with aspirin, ${ }^{9}{ }^{14}$ four examined clopidogrel plus aspirin compared with placebo plus aspirin, ${ }^{6-23}$ and one examined double dose compared with standard dose clopidogrel with higher or lower dose aspirin in a factorial design ${ }^{16}$ (table $1 \Downarrow$ ). Two studies examined prasugrel compared with clopidogrel ${ }^{15-22}$ and one study examined ticagrelor compared with clopidogrel, ${ }^{12}{ }^{21}$ all among patients also treated with aspirin (table 1). All original trials were of high quality as none exhibited high risk of bias on any Cochrane risk of bias tool domain (appendix). 


\section{Clopidogrel $v$ control arms}

Among the six studies that examined clopidogrel compared with control arms, all were conducted in patients with established cardiovascular disease. (The CHARISMA trial also included patients at high risk for cardiovascular events as defined by the presence of multiple risk factors, but only patients with established cardiovascular diseases were included in the smoking subgroup analysis. ${ }^{10}{ }^{11}$ ) One was conducted specifically in patients scheduled to undergo percutaneous coronary intervention. ${ }^{19}{ }^{20}$ Across trials, follow-up ranged from up to 30 days to up to three years. A total of 74489 patients, of whom $21717(29 \%)$ were smokers, were included in the meta-analysis of clopidogrel versus control arms.

In smokers, clopidogrel reduced the risk of the composite clinical endpoint by $25 \%$ (relative risk $0.75,95 \%$ confidence interval 0.67 to 0.83 ; fig $2 \Downarrow$ ). However, there was only an $8 \%$ reduction among nonsmokers $(0.92,0.87$ to 0.98$)$. No statistical heterogeneity was observed across studies in either smoking stratum $\left(Q=8.0, \mathrm{P}=0.16, \mathrm{I}^{2}=0.01\right.$ among smokers; $Q=5.3, \mathrm{P}=0.38$, $\mathrm{I}^{2}=0.00$ among nonsmokers).

We observed similar results in the sensitivity analysis in which we used the primary composite endpoint of thrombolysis in myocardial infarction (TIMI) flow grade (TFG) 0 or 1 or death or recurrent myocardial infarction before angiography could be performed from the CLARITY-TIMI 28 study. The fixed effects relative risk was 0.73 (95\% confidence interval 0.66 to 0.80 ) in smokers and 0.91 (0.86 to 0.96$)$ in nonsmokers. In this analysis, we did observe some heterogeneity in the smoker stratum $\left(Q=12.1, \mathrm{P}=0.03, \mathrm{I}^{2}=0.03\right)$ but not in the nonsmoker stratum $\left(Q=10.3, \mathrm{P}=0.07, \mathrm{I}^{2}=0.01\right)$. Results were consistent across sensitivity analyses in which we separately omitted a single study from the primary analysis (table $2 \Downarrow$ ). The small number of studies limits inference from the funnel plots (appendix), but no publication bias was apparent.

\section{Indirect comparison of antiplatelet agents}

Among smokers, prasugrel was associated with a further reduction in the composite endpoint compared with clopidogrel (relative risk $0.71,95 \%$ confidence interval 0.61 to 0.82 ; fig $3 \Downarrow$ ). The corresponding estimate comparing ticagrelor and clopidogrel was lower, at 0.83 (0.68 to 1.00). Both newer antiplatelet agents led to a lower incidence of the endpoint compared with the control arms of the clopidogrel trials (prasugrel $0.53,0.44$ to 0.64 ; ticagrelor $0.62,0.50$ to 0.78 ). The relative risk for prasugrel compared with ticagrelor in smokers was 0.85 (0.67 to 1.09 ).

In nonsmokers, we observed modest reductions in the composite endpoint for prasugrel compared with clopidogrel (relative risk $0.92,95 \%$ confidence interval 0.83 to 1.01 ) and for ticagrelor compared with clopidogrel $(0.89,0.79$ to 1.00 ; fig $3 \Downarrow)$. In indirect comparisons, nonsmokers given prasugrel $(0.85,0.76$ to 0.95$)$ and ticagrelor $(0.82,0.72$ to 0.93$)$ had lower incidence of the composite endpoint compared with the group of controls used in the clopidogrel trials. We found no difference between prasugrel versus ticagrelor $(1.03,0.88$ to 1.20$)$ among nonsmokers.

\section{Discussion}

This meta-analysis showed that in smokers, clopidogrel was associated with a $25 \%$ reduction in a composite outcome comprising cardiovascular death, myocardial infarction, and stroke, but there was only an $8 \%$ reduction among nonsmokers. Only two studies looked at prasugrel compared with clopidogrel and one looked at ticagrelor compared with clopidogrel; in these trials, the newer antiplatelet drugs seemed to be more efficacious than clopidogrel among smokers and marginally more efficacious than clopidogrel among nonsmokers. To our knowledge this is the first meta-analysis of data from randomized trials to assess the effect of smoking on the efficacy of antiplatelet drugs. Unlike the previously described "smoker's paradox, ${ }^{24}$ in which smokers were compared with nonsmokers, we evaluated the effect of antiplatelet treatment on cardiovascular outcomes in smokers and nonsmokers.

\section{Potential mechanisms}

Clopidogrel is a prodrug that undergoes a two step activation process mediated predominantly by the cytochrome $\mathrm{P} 450$ hepatic enzyme system. ${ }^{25}$ Polycyclic aromatic hydrocarbons in cigarette smoke are known to induce CYP1A2, an enzyme involved in the first activation step. Thus, smoking can enhance the availability of the active metabolite and reduce the proportion of prodrug eliminated without activation. ${ }^{26} \mathrm{~A}$ recent pharmacokinetic and pharmacodynamic study observed greater platelet inhibition by clopidogrel in smokers than in nonsmokers. ${ }^{27}$

While CYP1A2 induction offers one plausible explanation for enhanced clopidogrel activity, prasugrel, which is also a prodrug, undergoes a less complex activation process that is not believed to involve CYP1A2. ${ }^{28}$ We therefore hypothesized that smoking status would modify prasugrel's efficacy to a much lesser extent. Our analysis, however, found that the benefits of prasugrel and, to a lesser extent, ticagrelor, which is an active compound metabolized predominantly by CYP3A4, also seem enhanced among smokers. The previously mentioned pharmacokinetic and pharmacodynamic study also found greater platelet inhibition by prasugrel in smokers than in nonsmokers, but the results did not reach significance. ${ }^{27}$

In addition to metabolizing ticagrelor, CYP3A4 is also the primary hepatic enzyme involved in the conversion of prasugrel to its active metabolite and is also the main enzyme involved in the second step of clopidogrel's activation. ${ }^{28}$ While up-regulation of CYP3A4 would theoretically affect the metabolism of all three agents (but in different ways), and smoking has recently been observed to increase the induction of 3A4 in the presence of a known inducer, there is no strong evidence to suggest that smoking itself induces this enzyme. ${ }^{29}$ Alternatively, a pharmacodynamic mechanism could be responsible for the observed effects.

Although the exact mechanism by which smoking might enhance the activity of antiplatelet agents is not known, five out of the six studies in our analysis that compared clopidogrel with control arms found a larger benefit of clopidogrel in smokers than nonsmokers. We did not observe any statistical heterogeneity among results in each subgroup, despite minor differences in definitions of baseline smoking status, differences in patient populations, differences in control treatments, and differences in durations of follow-up. Our results were robust across sensitivity analyses, and we found no strong evidence for potential publication bias, though the number of studies was small, limiting such inference. Taken together, these results suggest that, at doses evaluated in phase III trials and currently used in practice, clopidogrel is associated with a substantial reduction in the composite outcome of cardiovascular death, myocardial infarction, and stroke among patients who smoke and only a modest benefit in patients who do not smoke. If confirmed, these findings might support different approaches to the use of these drugs in smokers and nonsmokers. 
Given that the efficacy of clopidogrel among smokers might be greater than expected based on overall trial results, it is critical to understand whether these patients are also at an increased risk of major bleeds, which could alter risk-benefit considerations. Of the studies identified in our systematic search, only the CHARISMA trial presented data on bleeding events in those randomized to clopidogrel compared with controls in smoking subgroups. The hazard ratios for severe or moderate bleeding for clopidogrel plus aspirin compared with aspirin alone were 1.31 (95\% confidence interval 0.90 to 1.90$)$ among never smokers, 1.43 (1.05 to 1.95) among former smokers, and 1.62 (1.02 to 2.58 ) among current smokers, suggesting a potential gradient of increased risk of bleeding across smoking status. ${ }^{10}$ The authors who investigated the effect of clopidogrel within smoking strata in the CLARITY-TIMI 28 trial noted that there was "no statistically significant interaction between smoking and clopidogrel on the risk of TIMI major or minor bleeding, ${ }^{13}$ but the analysis might have been underpowered for such an interaction test. In the TRILOGY trial, the hazard ratio for major bleeding related to non-coronary artery bypass grafting for prasugrel compared with clopidogrel was 1.72 (0.68 to 4.37) in current or recent smokers and 1.18 (0.68 to 2.05$)$ in not current or recent smokers. ${ }^{17}$ In the PLATO trial, the hazard ratio for major bleeding with ticagrelor compared with clopidogrel was 1.18 (0.98 to 1.43$)$ in current smokers and 1.04 (0.92 to 1.18 ) in former and nonsmokers. ${ }^{12}$

Our finding that clopidogrel confers little benefit among nonsmokers has particularly important implications in light of the decreasing prevalence of smoking in developed countries. Clinicians should carefully consider the potential benefits and risks of antiplatelet drugs differently for smokers and nonsmokers. In particular, these findings suggest that nonsmokers are likely to derive less benefit from treatment with antiplatelets. On the other hand, while smokers might be more likely to benefit from treatment, the enhanced antiplatelet effect might also increase the risk of bleeding, though this needs to be confirmed in future studies. Future studies should also investigate whether different doses should be used in smokers and nonsmokers.

We examined the possibility that our findings could be because smoking status is a marker for higher risk of cardiovascular outcomes. When data were available for each of the clopidogrel trials, we compared outcome frequencies among smokers and nonsmokers in the control groups. The cumulative incidence of the primary outcome was not systematically higher in smokers. Smokers had a higher incidence in the CREDO trial (13.8\% v $10.7 \%$ in nonsmokers $)^{19}$ but a lower incidence in

CURRENT-OASIS 7 (3.6\% v $4.8 \%$ in nonsmokers) ${ }^{16}$ and the CURE trial $(9.4 \%$ v $10.9 \%$ in never smokers and $13.1 \%$ in former smokers).$^{18}$ Incidences were similar for smokers and nonsmokers in the CAPRIE trial $(10.8 \% v 10.6 \%)^{14}$ and in CLARITY-TIMI 28 (13.9\% v 14.1\%). ${ }^{13}$ Furthermore, smokers tended to be younger and healthier than nonsmokers, and we did not find evidence of a greater effect of clopidogrel in other high risk subgroups. For example, the CURE investigators classified patients into low, intermediate, and high risk subgroups for the primary cardiovascular outcome and found that, compared with placebo, those in the high risk subgroup were least likely to benefit from clopidogrel. ${ }^{23}$

\section{Limitations}

The limitations of this study must be considered when interpreting its results. First, we relied on studies in the published literature, which could lead to distortions from publication bias. While our assessment for publication bias did not show major concerns, it was limited by the small number of studies. We do not expect much publication bias related to the primary results of large randomized trials, but we cannot rule out the possibility that ad hoc subgroup analyses of these trials have been conducted but not reported. Moreover, the subgroup analyses of smoking status were prespecified in some, but not all, of the original randomized trials. In addition, some of the data that we included were culled from conference abstracts that have not undergone rigorous peer review. Further, patient populations, study entry criteria, comparator treatments, trial durations, and classifications of smoking status differed among studies. Despite these differences, the results for clopidogrel compared with controls in smokers versus nonsmokers were consistent across studies and in sensitivity analyses. Our analyses require the assumption that randomization of treatment was successful within smoking subgroups, which is likely in such large trials. Finally, the indirect comparison methods require that the included trials be similar with respect to potential modifiers of treatment effect within smoking subgroups. The lack of observed heterogeneity suggests that this is true, at least for the clopidogrel trials. With respect to trials comparing prasugrel with clopidogrel, the application of this approach is limited by the fact that the TRITON-TIMI trial included patients scheduled to undergo percutaneous intervention, ${ }^{22}$ whereas the TRILOGY trial included patients not scheduled to undergo revascularization. ${ }^{17}$ The results stratified by smoking status, however, were qualitatively similar in these two trials.

\section{Conclusion}

On the whole, the available analyses of randomized trial subgroups suggest that the efficacy of antiplatelets differs among smokers and nonsmokers, with the benefit of these drugs occurring primarily among smokers and far less evidence of the drugs' efficacy in nonsmokers. Little is known about how smoking affects bleeding associated with antiplatelet treatment. Post hoc analyses of existing antiplatelet trials that collected baseline smoking information can both augment our efficacy findings and shed light on potential differences in bleeding risk associated with smoking status in patients treated with antiplatelets. Different risk-benefit considerations might be required for smokers and nonsmokers.

Contributors: JJG and KB were responsible for conception and design. All authors analysed and interpreted the data and revised the article for important intellectual content. JJG drafted the article and is guarantor.

Funding: This study was supported by internal funds within the Division of Pharmacoepidemiology and Pharmacoeconomics, Department of Medicine, Brigham and Women's Hospital and Harvard Medical School. Competing interests: All authors have completed the ICMJE uniform disclosure form at www.icmje.org/coi_disclosure.pdf (available on request from the corresponding author) and declare: no support from any organisation for the submitted work; no financial relationships with any organisations that might have an interest in the submitted work in the previous three years; no other relationships or activities that could appear to have influenced the submitted work.

Ethical approval: Not required.

Data sharing: Statistical code and datasets are available from the corresponding author.

1 Bowry AD, Brookhart MA, Choudhry NK. Meta-analysis of the efficacy and safety of clopidogrel plus aspirin as compared to antiplatelet monotherapy for the prevention of vascular events. Am J Cardiol 2008;101:960-6.

2 Gurbel PA, Nolin TD, Tantry US. Clopidogrel efficacy and cigarette smoking status. JAMA 2012;307:2495-6.

3 Moher D, Liberati A, Tetzlaff J, Altman DG. Preferred reporting items for systematic reviews and meta-analyses: the PRISMA statement. BMJ 2009;339:b2535. 


\section{What is already known on this topic}

Randomized trials report that adding clopidogrel to aspirin reduces the risk of the composite outcome of death, myocardial infarction, and stroke by $15 \%$ in patients with acute coronary syndromes

Concern has been raised that this benefit of clopidogrel might be more pronounced in smokers than in nonsmokers

\section{What this study adds}

This systematic review and meta-analysis of randomized trials found that clopidogrel reduced the composite outcome by $25 \%$ in smokers and by $8 \%$ in nonsmokers

In smokers, prasugrel and ticagrelor reduced the composite outcome by $29 \%$ and $17 \%$, respectively, compared with clopidogrel; whereas corresponding reductions in nonsmokers were only $8 \%$ and $11 \%$, respectively

Different risk-benefit considerations for antiplatelet drugs might be required for smokers and nonsmokers

4 Higgins JPT, Altman DG, Sterne JAC. Assessing risk of bias in included studies. In: Higgins JPT, Green S, eds. Cochrane Handbook for Systematic Reviews of Interventions. Cochrane Collaboration, 2011

5 Sabatine MS, McCabe CH, Gibson CM, Cannon CP. Design and rationale of clopidogrel as adjunctive reperfusion therapy-thrombolysis in myocardial infarction (CLARITY-TIMI) 28 trial. Am Heart J 2005:149:227-33.

6 Sabatine MS, Cannon CP, Gibson CM, Lopez-Sendon JL, Montalescot G, Theroux P, et al. Addition of clopidogrel to aspirin and fibrinolytic therapy for myocardial infarction with ST-segment elevation. N Engl J Med 2005;352:1179-89.

7 Egger M, Davey Smith G, Schneider M, Minder C. Bias in meta-analysis detected by a simple, graphical test. BMJ 1997;315:629-34.

8 Wells GA, Sultan SA, Chen L, Khan M, Coyle D. Indirect evidence: indirect treatment comparisons in meta-analysis. Canadian Agency for Drugs and Technologies in Health, 2009.

9 CAPRIE Steering Committee. A randomised, blinded, trial of clopidogrel versus aspirin in patients at risk of ischaemic events (CAPRIE). Lancet 1996;348:1329-39.

10 Berger JS, Bhatt DL, Steinhubl SR, Shao M, Steg PG, Montalescot G, et al. Smoking, clopidogrel, and mortality in patients with established cardiovascular disease. Circulation 2009;120:2337-44.

11 Bhatt DL, Fox KA, Hacke W, Berger PB, Black HR, Boden WE, et al. Clopidogrel and aspirin versus aspirin alone for the prevention of atherothrombotic events. N Engl J Med 2006;354:1706-17.

12 Cornel JH, Becker RC, Goodman SG, Husted S, Katus H, Santoso A, et al. Prior smoking status, clinical outcomes, and the comparison of ticagrelor with clopidogrel in acute coronary syndromes-insights from the PLATelet inhibition and patient Outcomes (PLATO) trial. Am Heart J 2012;164:334-42.e1.

13 Desai NR, Mega JL, Jiang S, Cannon CP, Sabatine MS. Interaction between cigarette smoking and clinical benefit of clopidogrel. J Am Coll Cardiol 2009;53:1273-8.

14 Ferreiro JL, Bhatt D, Ueno M, Bauer D, Angiolillo D. Differential effect of smoking on long-term outcomes in patients with atherosclerotic vascular disease treated with aspirin or clopidogrel: insights from the clopidogrel versus aspirin in patients at risk of ischemic events trial [abstract]. J Am Coll Cardiol 2012;59:A62.

15 Hochholzer W, Trenk D, Mega JL, Morath T, Stratz C, Valinia CM, et al. Impact of smoking on antiplatelet effect of clopidogrel and prasugrel after loading dose and on maintenance therapy. Am Heart J 2011;162:518-26.e5.

16 Mehta SR, Bassand JP, Chrolavicius S, Diaz R, Eikelboom JW, Fox KA, et al. Dose comparisons of clopidogrel and aspirin in acute coronary syndromes. $N$ Engl $\mathrm{J} \mathrm{Med}$ 2010;363:930-42.

17 Roe MT, Armstrong PW, Fox KA, White HD, Prabhakaren D, Goodman SG, et al. Prasugrel versus clopidogrel for acute coronary syndromes without revascularization. N Engl J Med 2012;367:1297-309.
18 Salek FS. Relationship between clopidogrel and cigarette smoking status in patients with acute coronary syndromes without ST-segment elevation myocardial infarction. Pharmacotherapy 2010;30:154e

19 Saraff KY, Steinhubl SR, Hsu AP, Topol EJ. Smoking influences the effectiveness of dual antiplatelet therapy on long-term outcomes following PCl. J Am Coll Cardiol 2006:47:36B.

20 Steinhubl SR, Berger PB, Mann JT, 3rd, Fry ET, DeLago A, Wilmer C, et al. Early and sustained dual oral antiplatelet therapy following percutaneous coronary intervention: a randomized controlled trial. JAMA 2002;288:2411-20.

21 Wallentin L, Becker RC, Budaj A, Cannon CP, Emanuelsson H, Held C, et al. Ticagrelor versus clopidogrel in patients with acute coronary syndromes. $N$ Engl $J$ Med 2009;361:1045-57.

22 Wiviott SD, Braunwald E, McCabe CH, Montalescot G, Ruzyllo W, Gottlieb S, et al. Prasugrel versus clopidogrel in patients with acute coronary syndromes. N Engl J Med 2007;357:2001-15

23 Yusuf S, Zhao F, Mehta SR, Chrolavicius S, Tognoni G, Fox KK. Effects of clopidogrel in addition to aspirin in patients with acute coronary syndromes without ST-segment elevation. N Engl J Med 2001;345:494-502.

24 Aune E, Roislien J, Mathisen M, Thelle DS, Otterstad JE. The "smoker's paradox" in patients with acute coronary syndrome: a systematic review. BMC Med 2011:9:97.

25 Clarke TA, Waskell LA. The metabolism of clopidogrel is catalyzed by human cytochrome P450 3A and is inhibited by atorvastatin. Drug Metab Dispos 2003;31:53-9.

26 Kroon LA. Drug interactions with smoking. Am J Health Syst Pharm 2007;64:1917-21.

27 Gurbel PA, Bliden KP, Logan DK, Kereiakes DJ, Lasseter KC, White A, et al. The influence of smoking status on the pharmacokinetics and pharmacodynamics of clopidogrel and prasugrel: the PARADOX Study. J Am Coll Cardiol 2013;62:505-12.

28 Farid NA, Kurihara A, Wrighton SA. Metabolism and disposition of the thienopyridine antiplatelet drugs ticlopidine, clopidogrel, and prasugrel in humans. J Clin Pharmacol 2010;50:126-42.

29 Rahmioglu N, Heaton J, Clement G, Gill R, Surdulescu G, Zlobecka K, et al. Genetic epidemiology of induced CYP3A4 activity. Pharmacogenet Genomics 2011;21:642-51.

\section{Accepted: 16 August 2013}

\section{Cite this as: BMJ 2013;347:f5307}

(c) Gagne et al 2013

This is an Open Access article distributed in accordance with the Creative Commons Attribution Non Commercial (CC BY-NC 3.0) license, which permits others to distribute, remix, adapt, build upon this work non-commercially, and license their derivative works on different terms, provided the original work is properly cited and the use is non-commercial. See: http://creativecommons.org/licenses/by-nc/3.0/. 


\section{Tables}

\begin{tabular}{|c|c|c|c|c|c|c|c|c|c|}
\hline Study & Patient population & Treatment 1 & Treatment 2 & $\begin{array}{l}\text { Outcome } \\
\text { definition }\end{array}$ & $\begin{array}{l}\text { Follow-up } \\
\text { duration }\end{array}$ & $\begin{array}{c}\text { Overall } \\
\text { incidence }\end{array}$ & $\begin{array}{l}\text { Smoking } \\
\text { subgroup }\end{array}$ & $\begin{array}{c}\text { No of } \\
\text { patients }\end{array}$ & $\begin{array}{l}\text { Relative risk } \\
(95 \% \mathrm{CI})\end{array}$ \\
\hline \multicolumn{10}{|c|}{ Clopidogrel $v$ control (aspirin, placebo, or low dose clopidogrel) } \\
\hline \multirow[t]{2}{*}{ CAPRIE $^{9,14}$} & \multirow{2}{*}{$\begin{array}{l}\text { Patients with } \\
\text { atherosclerotic } \\
\text { disease manifested } \\
\text { as either recent } \\
\text { ischemic stroke, } \\
\text { recent myocardial } \\
\text { infarction, or } \\
\text { symptomatic } \\
\text { peripheral artery } \\
\text { disease }\end{array}$} & \multirow[t]{2}{*}{$\begin{array}{l}\text { Clopidogrel } \\
75 \text { mg daily }\end{array}$} & \multirow[t]{2}{*}{$\begin{array}{l}\text { Aspirin } 325 \\
\text { mg daily }\end{array}$} & \multirow{2}{*}{$\begin{array}{l}\text { Composite of } \\
\text { death from } \\
\text { cardiovascular } \\
\text { causes, } \\
\text { nonfatal } \\
\text { myocardial } \\
\text { infarction, } \\
\text { nonfatal stroke }\end{array}$} & \multirow{2}{*}{$\begin{array}{l}\text { Up to } 3 \\
\text { years of } \\
\text { follow-up; } \\
\text { mean } \\
\text { follow-up, } \\
1.9 \text { years; } \\
\text { mean } \\
\text { treatment } \\
\text { duration, } 1.6 \\
\text { years }\end{array}$} & \multirow[t]{2}{*}{$10.2 \%$} & $\begin{array}{l}\text { Never and former } \\
\text { smokers }\end{array}$ & 13516 & $\begin{array}{c}0.98 \\
(0.88 \text { to } 1.09)^{*}\end{array}$ \\
\hline & & & & & & & Current smokers & 5688 & $\begin{array}{c}0.76 \\
(0.64 \text { to } 0.90)^{*}\end{array}$ \\
\hline \multirow[t]{2}{*}{ CURE $^{18,23}$} & \multirow{2}{*}{$\begin{array}{l}\text { Patients with acute } \\
\text { coronary } \\
\text { syndromes who did } \\
\text { not have ST } \\
\text { segment elevation } \\
\text { and treated with } \\
\text { aspirin }\end{array}$} & \multirow[t]{2}{*}{$\begin{array}{l}\text { Clopidogrel } \\
75 \text { mg daily }\end{array}$} & \multirow[t]{2}{*}{ Placebo } & \multirow{2}{*}{$\begin{array}{l}\text { Composite of } \\
\text { death from } \\
\text { cardiovascular } \\
\text { causes, } \\
\text { nonfatal } \\
\text { myocardial } \\
\text { infarction, } \\
\text { nonfatal stroke }\end{array}$} & \multirow{2}{*}{$\begin{array}{l}\text { Up to } 12 \\
\text { months; } \\
\text { mean } \\
\text { duration of } \\
\text { treatment, } 9 \\
\text { months }\end{array}$} & \multirow[t]{2}{*}{$10.3 \%$} & $\begin{array}{l}\text { Never and former } \\
\text { smokers }\end{array}$ & 9666 & $\begin{array}{c}0.85 \\
(0.76 \text { to } 0.96) \dagger\end{array}$ \\
\hline & & & & & & & Current smokers & 2893 & $\begin{array}{c}0.63 \\
(0.48 \text { to } 0.83)\end{array}$ \\
\hline \multirow[t]{2}{*}{ CREDO $^{19,20}$} & \multirow{2}{*}{$\begin{array}{l}\text { Patients who were } \\
\text { to undergo elective } \\
\mathrm{PCl} \text { or were } \\
\text { deemed at high } \\
\text { likelihood of } \\
\text { undergoing } \mathrm{PCl} \text { and } \\
\text { treated with aspirin }\end{array}$} & \multirow{2}{*}{$\begin{array}{l}\text { Clopidogrel } \\
300 \mathrm{mg} \\
\text { loading } \\
\text { dose before } \\
\mathrm{PCl} \\
\text { followed by } \\
75 \text { mg daily }\end{array}$} & \multirow{2}{*}{$\begin{array}{l}\text { Placebo } \\
\text { before PCl } \\
\text { followed by } \\
\text { clopidogrel } \\
75 \text { mg daily } \\
\text { through day } \\
28 \text { followed } \\
\text { by placebo }\end{array}$} & \multirow{2}{*}{$\begin{array}{l}\text { Composite of } \\
1 \text { year death, } \\
\text { myocardial } \\
\text { infarction, } \\
\text { stroke }\end{array}$} & \multirow[t]{2}{*}{$\begin{array}{l}\text { Up to } 12 \\
\text { months }\end{array}$} & \multirow[t]{2}{*}{$10.1 \%$} & Nonsmokers & 1433 & $\begin{array}{c}0.90 \\
(0.63 \text { to } 1.29) \ddagger\end{array}$ \\
\hline & & & & & & & Smokers & 647 & $\begin{array}{c}0.44 \\
(0.23 \text { to } 0.83)\end{array}$ \\
\hline \multirow[t]{2}{*}{$\begin{array}{l}\text { CLARITY-TIMI } \\
28^{6,13}\end{array}$} & \multirow{2}{*}{$\begin{array}{l}\text { Patients with ST } \\
\text { segment elevation } \\
\text { myocardial } \\
\text { infarction treated } \\
\text { with aspirin, a } \\
\text { fibrinolytic, and } \\
\text { heparin }\end{array}$} & \multirow[t]{2}{*}{$\begin{array}{l}\text { Clopidogrel } \\
75 \text { mg daily }\end{array}$} & \multirow[t]{2}{*}{ Placebo } & \multirow{2}{*}{$\begin{array}{l}30 \text { day } \\
\text { composite of } \\
\text { death from } \\
\text { cardiovascular } \\
\text { causes, } \\
\text { recurrent } \\
\text { nonfatal } \\
\text { myocardial } \\
\text { infarction, } \\
\text { recurrent } \\
\text { nonfatal } \\
\text { ischemia§ }\end{array}$} & \multirow{2}{*}{$\begin{array}{l}\text { Up to } 30 \\
\text { days of } \\
\text { follow-up }\end{array}$} & \multirow[t]{2}{*}{$12.7 \%$} & Nonsmokers & 1732 & $\begin{array}{c}0.91 \\
(0.68 \text { to } 1.20)\end{array}$ \\
\hline & & & & & & & Smokers & 1697 & $\begin{array}{c}0.64 \\
(0.47 \text { to } 0.89) 9\end{array}$ \\
\hline \multirow[t]{2}{*}{ CHARISMA $^{10,11}$} & \multirow[t]{2}{*}{$\begin{array}{l}\text { Patients with } \\
\text { evidence of } \\
\text { cardiovascular } \\
\text { disease treated with } \\
\text { aspirin }^{\star *}\end{array}$} & \multirow[t]{2}{*}{$\begin{array}{l}\text { Clopidogrel } \\
75 \mathrm{mg} \text { daily }\end{array}$} & \multirow[t]{2}{*}{ Placebo } & \multirow{2}{*}{$\begin{array}{l}\text { Composite of } \\
\text { death from } \\
\text { cardiovascular } \\
\text { causes, } \\
\text { nonfatal } \\
\text { myocardial } \\
\text { infarction, } \\
\text { nonfatal } \\
\text { stroke- }\end{array}$} & \multirow[t]{2}{*}{$\begin{array}{l}\text { Up to } 42 \\
\text { months of } \\
\text { follow-up; } \\
\text { median } \\
\text { follow-up, } \\
28 \text { months }\end{array}$} & \multirow[t]{2}{*}{$7.4 \%$} & $\begin{array}{l}\text { Never and former } \\
\text { (patients who } \\
\text { smoked } \geq 1 \\
\text { cigarette/day any } \\
\text { time before month } \\
\text { before enrollment) } \\
\text { smokers }\end{array}$ & 9733 & $\begin{array}{c}0.86 \\
(0.74 \text { to } \\
1.00) \dagger \dagger\end{array}$ \\
\hline & & & & & & & $\begin{array}{l}\text { Current smokers } \\
\text { (patients who } \\
\text { smoked } \geq 1 \\
\text { cigarette/day during } \\
\text { month before } \\
\text { enrollment) }\end{array}$ & 2419 & $\begin{array}{c}0.93 \\
(0.71 \text { to } 1.22)\end{array}$ \\
\hline \multirow[t]{2}{*}{$\begin{array}{l}\text { CURRENT-OASIS } \\
7^{16}\end{array}$} & $\begin{array}{l}\text { Patients with acute } \\
\text { coronary syndrome } \\
\text { referred for an }\end{array}$ & $\begin{array}{l}\text { Clopidogrel } \\
600 \mathrm{mg} \\
\text { loading }\end{array}$ & $\begin{array}{l}\text { Clopidogrel } \\
300 \mathrm{mg} \\
\text { loading }\end{array}$ & $\begin{array}{l}30 \text { day } \\
\text { composite of } \\
\text { death from }\end{array}$ & $\begin{array}{l}\text { Up to } 30 \\
\text { days of } \\
\text { follow-up }\end{array}$ & $4.3 \%$ & $\begin{array}{l}\text { Not current tobacco } \\
\text { users }\end{array}$ & 16701 & $\begin{array}{c}0.99 \\
(0.87 \text { to } \\
1.15) \neq \ddagger\end{array}$ \\
\hline & $\begin{array}{l}\text { and treated with } \\
\text { either higher dose } \\
\text { (300-325 mg daily) } \\
\text { or lower dose ( } 75 \\
100 \text { mg daily) } \\
\text { aspirin }\end{array}$ & $\begin{array}{l}\text { followed by } \\
150 \mathrm{mg} \\
\text { daily for } 6 \\
\text { days and } \\
75 \mathrm{mg} \\
\text { thereafter }\end{array}$ & $\begin{array}{l}\text { followed by } \\
75 \mathrm{mg} \\
\text { thereafter }\end{array}$ & $\begin{array}{l}\text { causes, } \\
\text { nonfatal } \\
\text { myocardial } \\
\text { infarction, } \\
\text { nonfatal stroke }\end{array}$ & & & $\begin{array}{l}\text { Current tobacco } \\
\text { users }\end{array}$ & 8373 & $\begin{array}{l}0.80 \\
(0.64 \text { to } \\
1.02) \ddagger \ddagger\end{array}$ \\
\hline
\end{tabular}


Table 1 (continued)

\begin{tabular}{|c|c|c|c|c|c|c|c|c|c|}
\hline Study & Patient population & Treatment 1 & Treatment 2 & $\begin{array}{l}\text { Outcome } \\
\text { definition }\end{array}$ & $\begin{array}{l}\text { Follow-up } \\
\text { duration }\end{array}$ & $\begin{array}{c}\text { Overall } \\
\text { incidence }\end{array}$ & $\begin{array}{l}\text { Smoking } \\
\text { subgroup }\end{array}$ & $\begin{array}{c}\text { No of } \\
\text { patients }\end{array}$ & $\begin{array}{c}\text { Relative risk } \\
\qquad(95 \% \mathrm{Cl})\end{array}$ \\
\hline \multicolumn{10}{|c|}{ Prasugrel $v$ clopidogrel } \\
\hline \multirow[t]{2}{*}{$\begin{array}{l}\text { TRITON-TIMI } \\
38^{15,22}\end{array}$} & \multirow{2}{*}{$\begin{array}{l}\text { Patients with } \\
\text { moderate to high } \\
\text { risk acute coronary } \\
\text { syndromes with } \\
\text { scheduled } \mathrm{PCl} \text { and } \\
\text { treated with aspirin }\end{array}$} & \multirow[t]{2}{*}{$\begin{array}{l}\text { Prasugrel } \\
10 \text { mg daily }\end{array}$} & \multirow[t]{2}{*}{$\begin{array}{l}\text { Clopidogrel } \\
75 \text { mg daily }\end{array}$} & \multirow{2}{*}{$\begin{array}{l}\text { Composite of } \\
\text { death from } \\
\text { cardiovascular } \\
\text { causes, } \\
\text { nonfatal } \\
\text { myocardial } \\
\text { infarction, } \\
\text { nonfatal stroke }\end{array}$} & \multirow{2}{*}{$\begin{array}{l}\text { Up to } 15 \\
\text { months of } \\
\text { follow-up; } \\
\text { median } \\
\text { duration of } \\
\text { treatment, } \\
14.5 \text { months }\end{array}$} & \multirow[t]{2}{*}{$11.0 \%$} & Nonsmokers & $8437 \S \S$ & $\begin{array}{c}0.84 \\
(0.74 \text { to } 0.96)\end{array}$ \\
\hline & & & & & & & Smokers & $5171 \S \S$ & $\begin{array}{c}0.76 \\
(0.64 \text { to } 0.91)\end{array}$ \\
\hline \multirow[t]{2}{*}{ TRILOGY ${ }^{17}$} & \multirow{2}{*}{$\begin{array}{l}\text { Patients aged }<75 \\
\text { with acute coronary } \\
\text { syndromes treated } \\
\text { with aspirin and not } \\
\text { scheduled to } \\
\text { undergo } \\
\text { revascularization } \llbracket \uparrow\end{array}$} & \multirow{2}{*}{$\begin{array}{l}\text { Prasugrel } \\
10 \text { mg daily }\end{array}$} & \multirow[t]{2}{*}{$\begin{array}{l}\text { Clopidogrel } \\
75 \text { mg daily }\end{array}$} & \multirow{2}{*}{$\begin{array}{l}\text { Composite of } \\
\text { death from } \\
\text { cardiovascular } \\
\text { causes, } \\
\text { nonfatal } \\
\text { myocardial } \\
\text { infarction, } \\
\text { nonfatal stroke }\end{array}$} & \multirow{2}{*}{$\begin{array}{l}\text { Up to } 30 \\
\text { months of } \\
\text { treatment; } \\
\text { median } \\
\text { follow-up, } \\
17.1 \\
\text { months; } \\
\text { median } \\
\text { duration of } \\
\text { treatment, } \\
14.8 \text { months }\end{array}$} & \multirow[t]{2}{*}{$14.9 \%$} & $\begin{array}{l}\text { Not current or } \\
\text { recent smoker }\end{array}$ & 5614 & $\begin{array}{c}1.06 \\
(0.90 \text { to } 1.24)\end{array}$ \\
\hline & & & & & & & $\begin{array}{l}\text { Current or recent } \\
\text { smoker (patients } \\
\text { who smoked } \\
\text { cigarettes within } 30 \\
\text { days before } \\
\text { randomization) }\end{array}$ & 1566 & $\begin{array}{c}0.54 \\
(0.39 \text { to } 0.74)\end{array}$ \\
\hline \multicolumn{10}{|c|}{ Ticagrelor $v$ clopidogrel } \\
\hline \multirow[t]{2}{*}{ PLATO $^{12,21}$} & \multirow[t]{2}{*}{$\begin{array}{l}\text { Patients with acute } \\
\text { coronary } \\
\text { syndromes treated } \\
\text { with aspirin }\end{array}$} & \multirow[t]{2}{*}{$\begin{array}{l}\text { Ticagrelor } \\
90 \mathrm{mg} \\
\text { twice daily }\end{array}$} & \multirow[t]{2}{*}{$\begin{array}{l}\text { Clopidogrel } \\
75 \text { mg daily }\end{array}$} & \multirow[t]{2}{*}{$\begin{array}{l}\text { Composite of } \\
\text { death from } \\
\text { cardiovascular } \\
\text { causes, } \\
\text { nonfatal } \\
\text { myocardial } \\
\text { infarction, } \\
\text { nonfatal stroke }\end{array}$} & \multirow[t]{2}{*}{$\begin{array}{l}\text { Up to } 12 \\
\text { months of } \\
\text { follow-up; } \\
\text { median } \\
\text { duration of } \\
\text { treatment, } \\
9.1 \text { months }\end{array}$} & \multirow[t]{2}{*}{$10.8 \%$} & $\begin{array}{l}\text { Nonsmokers } \\
\text { (patients who } \\
\text { reported no current } \\
\text { or previous } \\
\text { smoking) and } \\
\text { ex-smokers } \\
\text { (patients who } \\
\text { previously smoked } \\
\text { but stopped more } \\
\text { than month before } \\
\text { randomization) }\end{array}$ & $9311^{\star \star \star}$ & $\begin{array}{c}0.89 \\
(0.79 \text { to } 1.00)\end{array}$ \\
\hline & & & & & & & $\begin{array}{l}\text { Habitual smokers } \\
\text { (patients who } \\
\text { reported smoking } \\
\geq 1 \text { cigarette, cigar, } \\
\text { or equivalent } \\
\text { tobacco/day) }\end{array}$ & $5196^{\star \star \star}$ & $\begin{array}{c}0.83 \\
(0.68 \text { to } 1.00)\end{array}$ \\
\hline
\end{tabular}

$\mathrm{PCl}=$ percutaneous coronary intervention.

*Hazard ratios and 95\% confidence intervals from Gurbel et al. ${ }^{2}$

†Combined estimates for never and former smokers with fixed effects meta-analysis.

¥Cumulative incidence ratio and 95\% confidence intervals calculated from abstract presented at Innovation in Intervention: i2 Summit $2006 .{ }^{19}$

§Primary endpoint in CLARITY-TIMI 28 study was composite of thrombolysis in myocardial infarction (TIMI) flow grade (TFG) 0 or 1 or death or recurrent myocardial infarction before angiography could be performed. We selected 30 day clinical endpoint, which is more consistent with primary endpoints of other trials.

ICombined estimates from 1-9, 10-19, 20-29, and $\geq 30$ cigarettes/day subgroups with fixed effects meta-analysis.

${ }^{* *}$ CHARISMA trial included patients with established cardiovascular disease as well as those at high risk for cardiovascular events as defined by presence of multiple risk factors, but patients without established cardiovascular disease were excluded from post hoc smoking analysis because smoking was entry criterion for such patients.

††Combined estimates for never and former smokers with fixed effects meta-analysis.

$\neq \ddagger$ Calculated $95 \%$ confidence intervals from data in figure 3 of CURRENT-OASIS 7 publication. ${ }^{16}$

§§stimated from TRITON-TIMI 38 original publication (38\% of 13608 patients had tobacco use at baseline). ${ }^{22}$

IๆTRILOGY trial included secondary population comprising patients aged $\geq 75$ in whom prasugrel 5 mg was compared with clopidogrel 75 mg. Results stratified

by smoking status were available only for primary cohort of patients aged $<75$ in whom prasugrel $10 \mathrm{mg}$ was compared with clopidogrel $75 \mathrm{mg}$.

*** PLATO trial enrolled 18624 patients, but only 14507 were included in analysis stratified by smoking status. 
Table 2| Sensitivity analyses omitting each study one at a time from primary analysis of clopidogrel compared with controls and efficacy of antiplatelet drugs in prevention of cardiovascular events

\begin{tabular}{lcc}
\multirow{2}{*}{\begin{tabular}{l} 
Study omitted \\
\cline { 2 - 3 } None (primary analysis)
\end{tabular}} & \multicolumn{2}{c}{ Relative risk (95\% Cl) } \\
\hline CAPRIE & $0.74(0.67$ to 0.83$)$ & $0.92(0.87$ to 0.98$)$ \\
\hline CURE 0.84$)$ & $0.90(0.84$ to 0.96$)$ \\
\hline CREDO & $0.77(0.69$ to 0.86$)$ & $0.95(0.87$ to 1.02$)$ \\
\hline CLARITY-TIMI 28 & $0.76(0.68$ to 0.85$)$ & $0.92(0.87$ to 0.98$)$ \\
\hline CHARISMA & $0.72(0.64$ to 0.80$)$ & $0.93(0.88$ to 0.99$)$ \\
\hline CURRENT-OASIS 7 & $0.73(0.65$ to 0.82$)$ & $0.90(0.85$ to 0.97$)$ \\
\hline
\end{tabular}




\section{Figures}

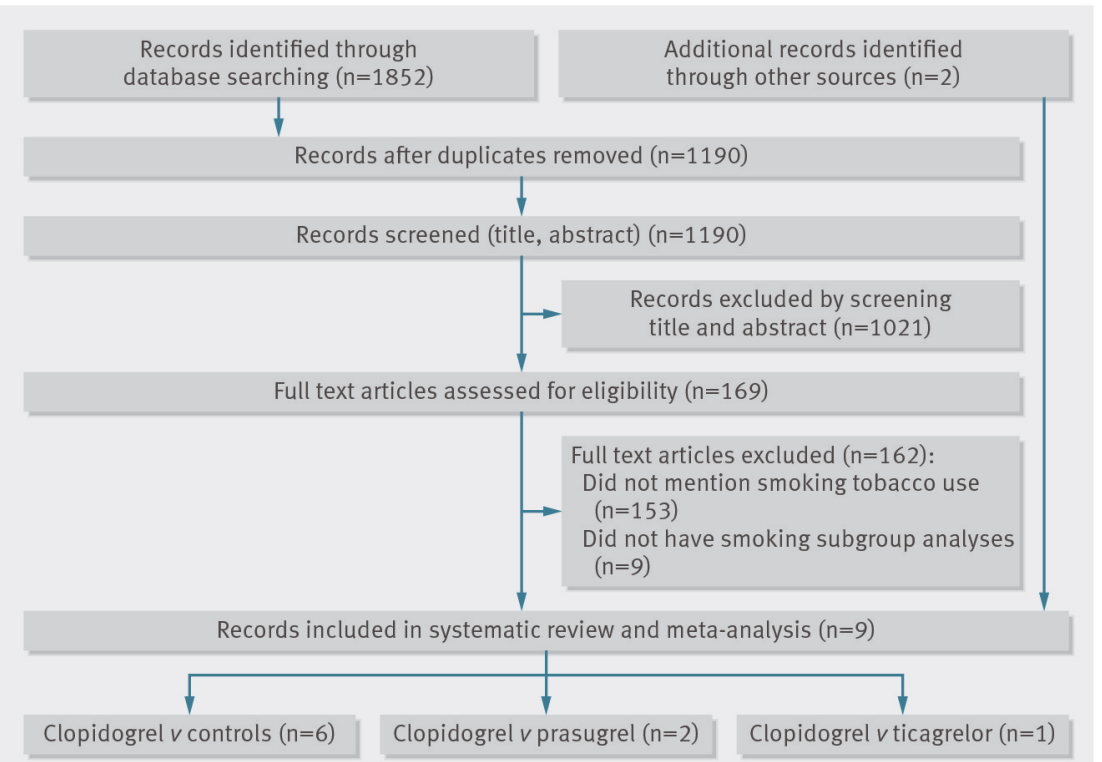

Fig 1 Flow of identification and inclusion of studies of antiplatet drugs

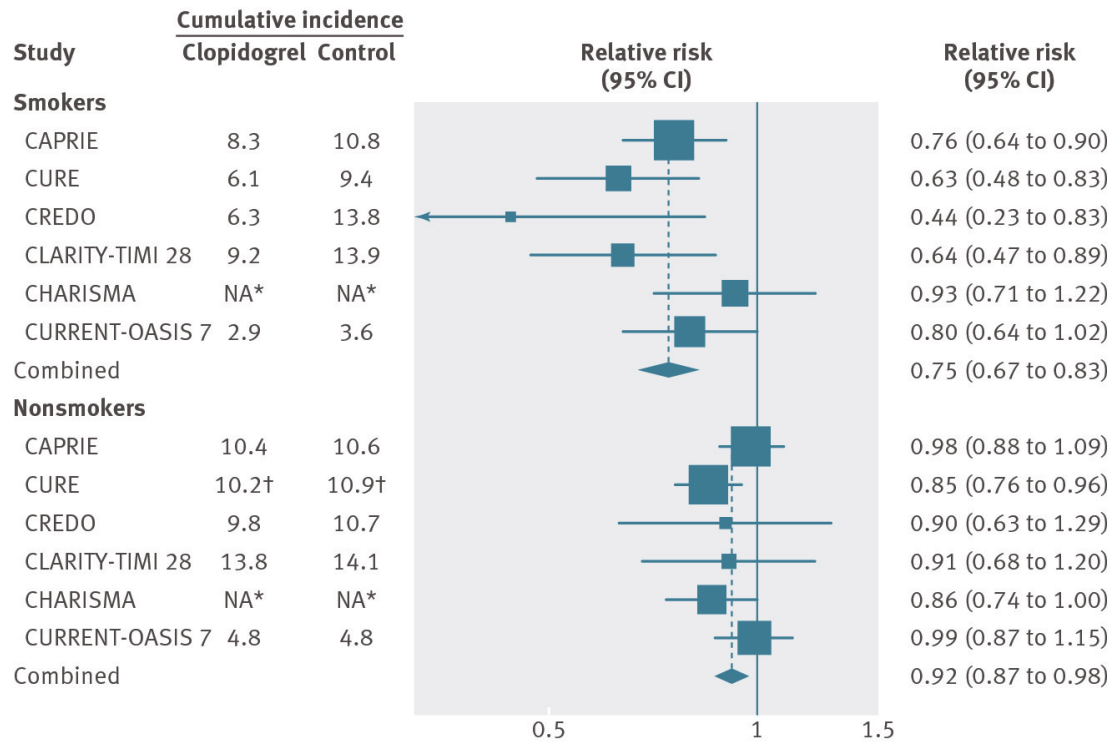

Fig 2 Efficacy of clopidogrel stratified by baseline smoking status. *Cumulative incidences in each treatment arm were not reported within smoking subgroups in CHARISMA trial. †Cumulative incidences presented here for CURE trial are only for never smokers. Cumulative incidences for former smokers were $10.3 \%$ in clopidogrel arm and $13.1 \%$ in control arm 


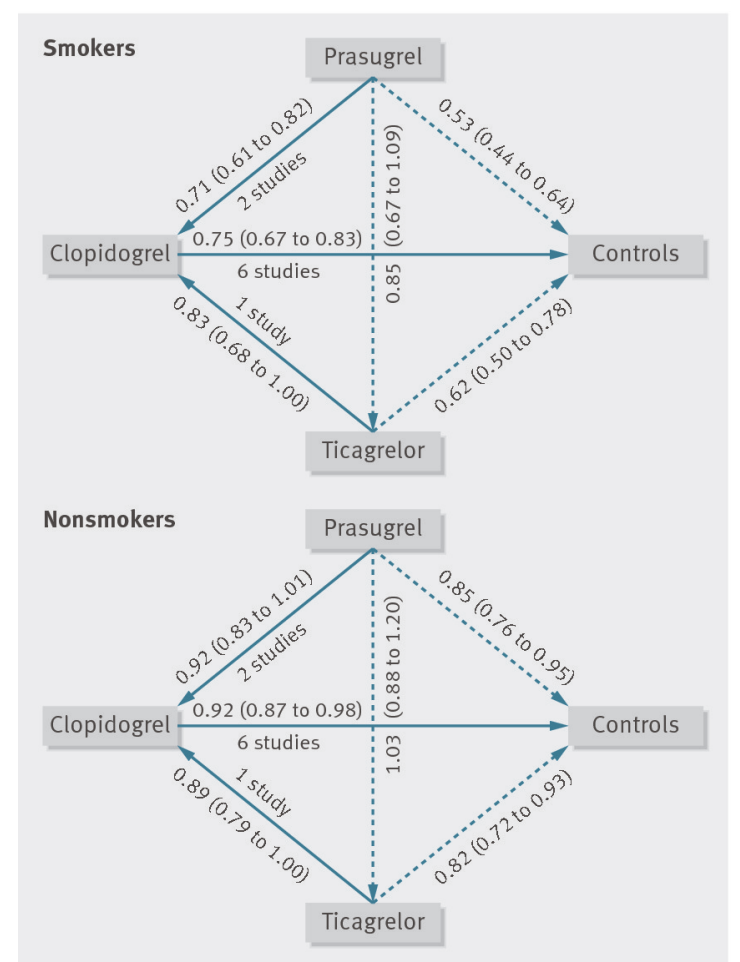

Fig 3 Hazard ratios for clopidogrel, prasugrel, ticagrelor, and controls in mixed treatment comparisons. Solid lines indicate estimates based on direct comparisons between two treatments. Dashed lines indicate estimates derived from indirect comparisons 